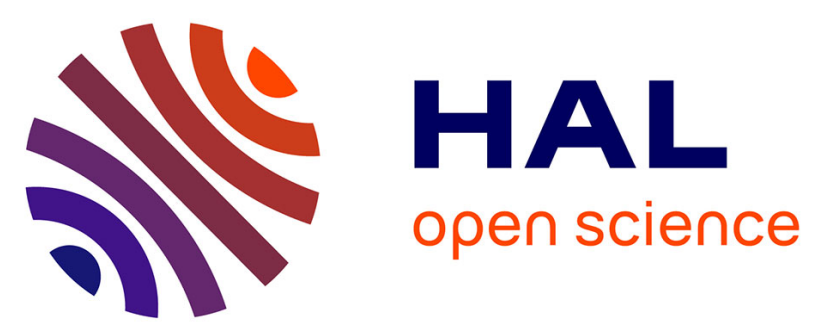

\title{
Fitness costs of insecticide resistance in natural breeding sites of the mosquito culex pipiens
}

\author{
Denis D. Bourguet, Thomas Guillemaud, Christine Chevillon, Michel \\ Raymond
}

\section{- To cite this version:}

Denis D. Bourguet, Thomas Guillemaud, Christine Chevillon, Michel Raymond. Fitness costs of insecticide resistance in natural breeding sites of the mosquito culex pipiens. Evolution - International Journal of Organic Evolution, 2004, 58 (1), pp.128-135. 10.1111/j.0014-3820.2004.tb01579.x . hal02674721

\section{HAL Id: hal-02674721 \\ https://hal.inrae.fr/hal-02674721}

Submitted on 15 Sep 2020

HAL is a multi-disciplinary open access archive for the deposit and dissemination of scientific research documents, whether they are published or not. The documents may come from teaching and research institutions in France or abroad, or from public or private research centers.
L'archive ouverte pluridisciplinaire HAL, est destinée au dépôt et à la diffusion de documents scientifiques de niveau recherche, publiés ou non, émanant des établissements d'enseignement et de recherche français ou étrangers, des laboratoires publics ou privés. 


\title{
FITNESS COSTS OF INSECTICIDE RESISTANCE IN NATURAL BREEDING SITES OF THE MOSQUITO CULEX PIPIENS
}

\author{
Denis Bourguet, ${ }^{1,2}$ Thomas Guillemaud, ${ }^{1,3}$ Christine Chevillon, ${ }^{1,4}$ And Michel Raymond ${ }^{1,5}$ \\ ${ }^{1}$ Institut des Sciences de l'Evolution, Université de Montpellier II, 34095 Montpellier, France \\ ${ }^{2}$ Unité Génétique Microbienne et Environnement, Institut National de la Recherche Agronomique La Minière, \\ 78285 Guyancourt, France \\ ${ }^{3}$ Equipe Biologie des Populations en Interaction, UMR 1112, INRA-UNSA, 06606 Antibes, France \\ ${ }^{5}$ E-mail: raymond@isem.univ-montp2.fr.
}

\begin{abstract}
Genetic changes conferring adaptation to a new environment may induce a fitness cost in the previous environment. Although this prediction has been verified in laboratory conditions, few studies have tried to document this cost directly in natural populations. Here, we evaluated the pleiotropic effects of insecticide resistance on putative fitness components of the mosquito Culex pipiens. Experiments using different larval densities were performed during the summer in two natural breeding sites. Two loci that possess alleles conferring organophosphate (OP) resistance were considered: ace-1 coding for an acetylcholinesterase (AChE1, the OP target) and Ester, a "super locus" including two closely linked loci coding for esterases A and B. Resistance ace-1 alleles coding for a modified AChE1 were associated with a longer development time and shorter wing length. The pleiotropic effects of two resistance alleles Ester $^{1}$ and Ester ${ }^{4}$ coding for the overproduced esterases A1 and A4-B4, respectively, were more variable. Both A1 and A4-B4 reduced wing length, although only A1 was associated with a longer preimaginal stage. The fluctuating asymmetry (FA) of the wing did not respond to the presence or to the interaction of resistance alleles at the two loci at any of the density levels tested. Conversely, the FA of one wing section decreased when larval density increased. This may be the consequence of selection against less developmentally stable individuals. The results are discussed in relation to the local evolution of insecticide resistance genes.
\end{abstract}

Key words.—Development time, fitness components, fluctuating asymmetry, insensitive acetylcholinesterase, overproduced esterases, wing length.

Crow (1957) was the first to predict that resistance alleles should initially be disadvantageous in the absence of selection. This prediction has since been verified in plants for herbicides, pathogens, and herbivores (reviews in Simms and Rausher 1987; Simms and Triplett 1994; Bergelson and Purrington 1996), in bacteria for antibiotic resistance (review in Anderson and Levin 1999) and in many pest species for pesticide resistance (reviews in Roush and McKenzie 1987; Coustau et al. 2000).

Two general methods have been used to study the fitness costs of insecticide resistance alleles (Crow 1957). The first involves following changes in the frequencies of resistance alleles in populations that were not treated with pesticides for several generations (e.g., Cochran 1993; Zhai and Robinson 1996), in overwintering populations (e.g., Daly and Fitt 1990; McKenzie 1990; Chevillon et al. 1997) or in populations located along a transect between treated and untreated areas (Lenormand et al. 1999). The second involves comparing fitness components between resistant and susceptible individuals. Although the first method is the only one that can estimate complete fitness costs, it does not provide detailed information about the specific mechanisms underlying these costs.

Studies on fitness components of resistant individuals in the absence of chemical treatment were rather neglected until the 1970s (Roush and McKenzie 1987) and remain insufficient (Taylor and Feyereisen 1996; Coustau et al. 2000). In addition, most published data suffer from three weaknesses.

\footnotetext{
${ }^{4}$ Present address: Centre d'Etude sur le Polymorphisme de Microorganismes, UMR CNRS-IRD 9926, BP 64501, 34394 Montpellier, France.
}

First, comparisons generally involve unrelated resistant and susceptible strains (e.g., Baker et al. 1998; Alyokhin and Ferro 1999). As pointed out 50 years ago by Varzandeh et al. (1954), resistant and susceptible strains may differ in many other genes than those involved in resistance. This is particularly relevant because populations from different geographical origins often differ in trait life history (Whitehead et al. 1985). In addition, reference susceptible strains have usually been maintained in the laboratory for decades and therefore may be adapted to laboratory conditions. Unless compared in a similar genetic background, there is no guarantee that the effects measured are truly due to the resistance alleles. Unfortunately, only a few studies have properly controlled for the effect of the genetic background. One way is to repeatedly backcross the resistant individuals with the susceptible one so that the genetic background of the resistant strain is replaced by that of the susceptible one (e.g., Amin and White 1984; Argentine et al. 1989). A second procedure is to analyze the correlation between insecticide susceptibility and life-history traits in different natural populations, strains, or crosses (e.g., Campanhola et al. 1991; Raymond et al. 1993; Hollingworth et al. 1997; Foster et al. 1999).

The second weakness of studies on fitness costs is that they have generally been performed in optimal conditions (but see McKenzie et al. 1982; Heather 1982; Zhu et al. 1996). However, the metabolic and/or physiological modifications induced by resistance alleles may be more deleterious in adverse conditions.

Third, most studies have been conducted in artificial laboratory conditions and consequently suffer from the problem of uncertain relevance to field conditions (Roush and 
McKenzie 1987; Roush and Daly 1990). Therefore, there is still a crucial need for direct estimations of the fitness costs of insecticide resistance alleles in natural populations.

Insecticide resistance in Culex pipiens mosquitoes is a convenient model for this type of study. In this species, two main loci are responsible for organophosphate (OP) resistance. The first locus, ace-1, codes for an acetylcholinesterase (AChE1), which is the target of OP (Bourguet et al. 1996a; Malcolm et al. 1998; Weill et al. 2002). The second locus, Ester, is a "super locus", including two closely linked loci (Est-2 and Est-3) coding for esterases B and A, respectively (DeStordeur 1976; Pasteur et al. 1981a,b). Three ace-1 allelic classes have been described: (1) ace- $1^{S}$, which includes all the alleles coding for sensitive AChE1, (2) ace- $1^{R}$, coding for an insensitive $\mathrm{AChE1}$, and (3) ace- $1^{R S}$, corresponding to a duplication of ace-1 and coding for both enzymes (Bourguet et al. 1996b; Lenormand et al. 1998a). Resistance alleles at Ester induce an overproduction of esterase due to either gene amplification or gene regulation (Rooker et al. 1996). In southern France, two main resistance alleles have been identified at the Ester locus: Ester ${ }^{1}$, which causes overproduction of esterase A1, and Ester ${ }^{4}$ (which corresponds to a coamplification of the Est-2 and Est-3 loci), which causes overproduction of esterases A4 and B4 (designated A4-B4). Alleles displaying a normal esterase level at both Est-2 and Est-3 are referred to as Ester ${ }^{\circ}$.

Organophosphate resistance alleles at both loci are costly in the field, notably during the overwintering period (review in Raymond et al. 2001). The overall cost during the summer has been evaluated by Lenormand et al. (1999), but it is not known which components of fitness are affected. Therefore, the aim of the present study was to investigate some morphological and developmental traits that may be modified in resistant individuals (displaying either Ester ${ }^{1}$, Ester $^{4}$, ace $1^{R}$ or ace-1 $1^{R S}$ ) compared to susceptible individuals (displaying Ester ${ }^{0}$ and ace $^{-I^{S}}$ alleles). We detected these pleiotropic effects by manipulating larval densities in the field and by evaluating various putative components of fitness, including the fluctuating asymmetry (FA; Markow 1995; Møller 1997, 1999; Clarke 1998).

\section{Materials And Methods}

\section{Mosquito Samples}

The experiment took place in two breeding sites near Montpellier in southern France: Etang-de-Pérols $\left(43^{\circ} 19^{\prime} 47^{\prime \prime} \mathrm{N} 3^{\circ} 33^{\prime}\right.$ $\left.36^{\prime \prime} \mathrm{E}\right)$ and Notre-Dame-de-Londres (43⒉ $\left.24^{\prime \prime} \mathrm{N} 3^{\circ} 28^{\prime} 12^{\prime \prime} \mathrm{E}\right)$. The main difference between the two sites was that the former was located in the insecticide-treated area whereas the latter was located outside this area. Thus, we expected to have higher insecticide resistance phenotype frequencies at Etang-de-Pérols than at Notre-Dame-de-Londres. A total of 30 freshly laid egg rafts of $C$. pipiens was collected at Etang-de-Pérols on 2 June 1993 and at Notre-Dame-de-Londres on 8 June 1993, and allowed to hatch in the laboratory. All collected egg rafts were still unmelanized, so they were less than two hours old (Clements 1992). Hatching occurred two days later and, for each site, larvae were randomly distributed amongst six tubes (9.5 cm diameter, immersed to a depth of $12.5 \mathrm{~cm}$, covered with a net at both ends) at densities of 150,300 , or 1000
TABLE 1. Correspondence between genotypes and phenotypes at the ace-1 and the Ester loci (see introduction for description of each allele).

\begin{tabular}{|c|c|c|}
\hline \multirow[b]{2}{*}{ Locus } & \multicolumn{2}{|c|}{ Coding rules } \\
\hline & Genotypes & Phenotypes \\
\hline \multirow[t]{6}{*}{ ace-1 } & ace- $I^{S}$ ace $-1^{S}$ & SS \\
\hline & ace $-I^{S}$ ace $-I^{R}$ & $\mathrm{RS}$ \\
\hline & ace $-1^{S}$ ace $-1^{R S}$ & RS \\
\hline & ace $-1^{R S}$ ace $-1^{R S}$ & $\mathrm{RS}$ \\
\hline & ace $-1^{R S}$ ace $-1^{R}$ & $\mathrm{RS}$ \\
\hline & ace $-1^{R}$ ace $-1^{R}$ & RR \\
\hline \multirow[t]{6}{*}{ Ester } & Ester $^{O}$ Ester $^{O}$ & 0 \\
\hline & Ester $^{0}$ Ester $^{l}$ & 1 \\
\hline & Ester $^{l}$ Ester ${ }^{l}$ & 1 \\
\hline & Ester $^{0}$ Ester $^{4}$ & 4 \\
\hline & Ester $^{4}$ Ester $^{4}$ & 4 \\
\hline & Ester $^{1}$ Ester $^{4}$ & 14 \\
\hline
\end{tabular}

larvae per tube with two replicates per density. These tubes were immediately placed in the corresponding native breeding site allowing larvae to develop in their natural environment. Pupae were collected from the twelve tubes on a daily basis, so that the length of larval development (variable $D E V$ ) could be estimated for each individual. For each tube, the mortality level was estimated by the difference between the initial larval density (i.e. 150, 300, or 1000 larvae) and the total number of pupae collected.

Pupae were transferred to the laboratory where emerging females were labeled according to their tube of origin and their day of emergence. The sampling protocol was designed so that all females of a given tube had the same probability of being sampled irrespectively of their day of emergence. A fixed proportion of the females emerging each day was sampled from each tube. A total of about 30 adults were sampled from each tube. All females were frozen at $-80^{\circ} \mathrm{C}$ before identification of insecticide resistance alleles and morphological measurements of the wing. Thus, a total of 354 adult females was analyzed for OP resistance allele, wing length, and fluctuating asymmetry.

\section{Identification of Insecticide Resistance Alleles}

For each of the 354 adult females, OP resistance alleles at the Ester and the ace-1 loci were determined as follows. The abdomen was used to detect overproduced esterases A1 and A4-B4 by starch gel electrophoresis as described in Pasteur et al. (1988). The head and thorax were used to determine the existence of sensitive and insensitive AChE1 using the microplate test described by Raymond and Marquine (1994). These biochemical methods did not allow complete genotype identification. Overproduced esterases are dominant markers under our electrophoretic conditions and the microplate test cannot discriminate between the different genotypes of individuals displaying both sensitive and insensitive AChE1. Thus, females were assigned by a biochemical phenotype following the nomenclature proposed by Lenormand et al. (1998a) as described in Table 1.

\section{Morphological Measurements}

Both wings of each female were mounted on a slide. The length of each wing was measured using landmarks described 


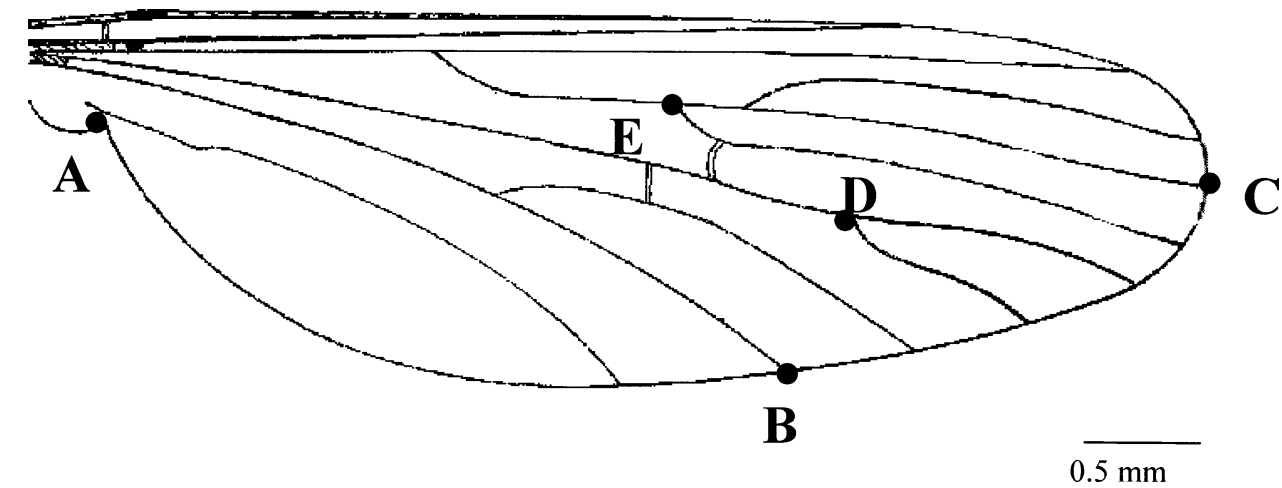

FIG. 1. Right wing of Culex pipiens and measurements used to define morphological variables. Sections 1,2 , and 3 and wing length $(L)$ correspond to distances EC, ED, EB.

in Figure 1 and the mean length was used as variable $L$. For asymmetry analysis, three sections (1, 2, and 3, Fig. 1) were measured twice on both wings by only one of the authors (D. Bourguet). The second measurement was made without knowledge of the first one. Due to wing alterations, sections 1,2 , and 3 were measured on 270, 265, and 245 females, respectively.

\section{Developmental Time and Wing Length}

Given the importance of life-history traits in determining reproductive success (Roff 1992; Stearns 1992), the pleiotropic effects of insecticide resistance alleles on developmental time and wing length can affect fitness. First, there is a positive correlation between wing length and fecundity in many mosquitoes (Nasci 1986; Packer and Corbet 1989; Briegel 1990). Second, variation in larval development time is the primary source of variation in mean generation time in developing populations of mosquitoes (Moeur and Istock 1980), and mean generation time is a fundamental component of fitness in expanding populations (Charlesworth 1980). In addition, in the presence of larval predators or parasites, a delay in development may also lower the probability of surviving the larval stage, hence decreasing fitness (Agnew and Koella 1999; Yan et al. 1997).

Pleiotropic effect of resistance genes._Each female was characterized by seven variables: breeding site (qualitative variable SITE, two levels), the larval density of the tube in which it grew (qualitative variable DENSITY, three levels), the replicate number (qualitative variable $R E P$, two levels), larval developmental time (quantitative variable $D E V$ ), resistance type (qualitative variables ESTER and $A C E 1$, with four and three levels respectively), and mean wing length (quantitative variable $L$ ). The effect of resistance type on larval developmental time and wing length was estimated as follows. For the dependent variable $D E V$ (which was log-transformed to normalize the residuals), the model SITE + DENSITY + SITE.DENSITY + SITE.DENSITY.REP + ACE1 + ESTER + ACE1.DENSITY + ESTER.DENSITY + ACE1.ESTER + ACE1.SITE + ESTER.SITE + ACE1.REP + ESTER.REP + SITE.DENSITY.ACE1 + SITE. DENSITY.ESTER + ACE1.ESTER.SITE + ACE1.ESTER.REP + $A C E 1 . E S T E R . D E N S I T Y+L$ (where a period indicates an interaction between two qualitative variables) was fitted to the data, to take into account the various correlations among variables and possible allometric effects. This model was then simplified: higher order terms were first tested, and the least and nonsignificant $(P>0.05)$ ones were removed. Factor levels of qualitative variables that were not different from one another in their parameter estimates were lumped together as described by Crawley (1993). This process gives the minimal adequate model. When variable $L$ was considered as dependent, it was replaced by $D E V$ from the model of independent variables, and the same procedure was applied. All these computations were performed with GLIM version 4 (Baker 1987).

\section{Fluctuating Asymmetry}

Test to determine whether FA is significantly larger than measurement error. - To determine whether the variation between the left and right wing was significantly larger than the measurement error, we used a simple two-way ANOVA (sides $\times$ individuals; Palmer and Strobeck 1986). Tests for FA differences are only justified if the interaction variance is significant.

Directional asymmetry (DA)._-For each section, departure of the mean of (R-L) from an expected mean of zero was tested using a paired $t$-test.

Fluctuating asymmetry (FA)._-Fluctuating asymmetry indices were the mean $|\mathrm{R}-\mathrm{L}|$ (i.e. $|\mathrm{R}-\mathrm{L}|$ averaged over the two replicates), known as Palmer FA1 index (Palmer 1994), or the mean $[|\mathrm{R}-\mathrm{L}| /((\mathrm{R}+\mathrm{L}) / 2)]$ over the two replicates, known as Palmer FA2 index (Palmer 1994), depending on whether FA1 clearly depended on trait size. The effect of the resistance genes ace-1 and Ester and their interactions on FA were tested by fitting the same model (see section Pleiotropic effect of resistance genes), with both $L$ and $D E V$ being present, and by using the same procedure for model simplification.

\section{RESUlts}

\section{Resistance Alleles in Breeding Sites}

Resistance alleles at the Ester and the ace-1 loci were present in both breeding sites. The overall frequencies of type 1 and 4 mosquitoes were $8.9 \%$ and $30.2 \%$ at Notre-Damede-Londres and $17.5 \%$ and $56.6 \%$ at Etang-de-Pérols, respectively. Phenotype 14 was absent at Notre-Dame-de-Londres and was found at a frequency of 5.4\% at Etang-de-Pérols. 
TABle 2. Estimates for developmental time (in days) for both breeding sites (site 1, Notre-Dame-de-Londres; site 2, Etang-de-Pérols) and both replicates. Estimates for the double susceptible class (mosquitoes 0 and SS) were used as a reference to calculate the additional effects of resistance genes, according to the resistance phenotype at ace-1 and Ester. Factor levels describing RS and RR individuals were lumped together because their estimated values were not different from one another. Similarly, factor levels describing 0 and 14 mosquitoes were lumped together.

\begin{tabular}{|c|c|c|c|c|c|c|c|c|c|c|}
\hline \multirow[b]{3}{*}{ Site } & \multirow[b]{3}{*}{ Replicate } & \multirow[b]{3}{*}{ Density $^{1}$} & \multirow{3}{*}{$\begin{array}{l}\text { Estimate (in days) } \\
\text { for SS and } 0\end{array}$} & \multicolumn{7}{|c|}{ Resistance phenotype } \\
\hline & & & & \multirow[b]{2}{*}{ Ester: } & \multicolumn{3}{|c|}{ ace-1: SS } & \multicolumn{3}{|c|}{$\mathrm{RS}$ or $\mathrm{RR}$} \\
\hline & & & & & 14 & 1 & 4 & 0 or 14 & 1 & 4 \\
\hline \multirow{4}{*}{ Site 1} & & 300 & 11.3 & & 0 & 1.71 & 0.84 & 0.93 & 1.36 & 1.40 \\
\hline & & 1000 & 14.3 & & 0 & 0.11 & -0.32 & 1.17 & -0.28 & 0.33 \\
\hline & Replicate 2 & 150 & 8.7 & & 0 & 0.69 & 0.15 & 0.67 & 0.45 & 0.54 \\
\hline & & 300 & 9.5 & & 0 & 1.36 & 0.66 & 0.73 & 1.08 & 1.11 \\
\hline \multirow{5}{*}{ Site 2} & & 300 & 18.0 & & 0 & 2.69 & 1.31 & 1.45 & 2.14 & 2.20 \\
\hline & & 1000 & 30.0 & & 0 & 0.23 & -0.67 & 2.43 & -0.58 & 0.68 \\
\hline & Replicate 2 & 150 & 14.0 & & 0 & 1.10 & 0.24 & 1.07 & 0.71 & 0.86 \\
\hline & & 300 & 16.2 & & 0 & 2.29 & 1.11 & 1.23 & 1.82 & 1.87 \\
\hline & & 1000 & 17.8 & & 0 & 0.13 & -0.37 & 1.35 & -0.32 & 0.38 \\
\hline
\end{tabular}

${ }^{1}$ Initial number of larvae per tube.

At the ace- 1 locus, $15.5 \%$ and $52.5 \%$ of individuals were RS, and $1 \%$ and $38.6 \%$ were RR at Notre-Dame-de-Londres and Etang-de-Pérols, respectively. These frequencies were consistent with previous estimates at these breeding sites (e.g., Chevillon et al. 1995; Guillemaud et al. 1998; Lenormand et al. 1998b) and allowed us to investigate variations in putative components of fitness.

\section{Larval Development and Wing Length}

Pleiotropic effect on larval development.-After simplification, the model describing the logarithm of larval development was SITE + DENSITY + SITE.DENSITY + SITE.DENSITY.REP + ESTER + ACE1 + ESTER.ACE $1+$ ESTER. DENSITY + L. Factor levels describing RS and RR individuals were lumped together because their estimated values were not different from one another $\left(F_{4,297}=1.63, P=\right.$ 0.17). Similarly, factor levels describing type 0 and 14 mosquitoes were lumped together $\left(F_{4,301}=0.88, P=0.48\right)$. The resulting model explained $93.1 \%$ of the total deviance. Residuals were normally distributed (Shapiro-Wilk test, $W=$ $0.9769, P=0.051$; when one outlier was removed, $W=$ $0.9855, P=0.65$ ). Each locus had a significant effect on development time (when all factors describing the resistance phenotypes pooled, ace-1: $F_{3,305}=6.10, P=0.0005$; Ester: $\left.F_{8,305}=2.78, P=0.0056\right)$. The effect of Ester was due to a significant effect of both 1 and 4 resistance phenotypes (pooling 0 and 1: $F_{4,305}=4.04, P=0.003$; pooling 0 and 4: $\left.F_{4,305}=3.07, P=0.017\right)$. The mean effect of resistance alleles at ace- 1 was an increase in developmental time compared to susceptible individuals. The mean effect of resistance genes at Ester was an increase in developmental time for type 1 and 4 mosquitoes compared to susceptible individuals, which was apparent at the lowest (for type 1) and the intermediate (for type 1 and 4 ) densities. These single locus effects were not additive due to the significant interaction term ESTER.ACE1 $\left(F_{6,293}=2.74, P=0.013\right)$. The corresponding increase in additional days of larval development varied positively according to wing size, and also varied according to the other confounding variables. The presence of resistance alleles altered developmental time by about $-0.7-2.5$ days depending on the exact resistance alleles involved (up to 2.7 days for type 1 individuals in one replicate), corresponding to a variation of $-2.3-15 \%$. The precise value of variations in developmental time for both replicates and all densities at both sites are given in Table 2 .

Pleiotropic effect on wing length.-After simplification, the model describing the wing size was SITE + DENSITY + SITE.DENSITY + SITE.DENSITY.REP + ESTER + ACE $1+$ $D E V$. Factor levels describing $\mathrm{RS}$ and $\mathrm{SS}$ individuals were lumped together as their estimated values were not different from one another $\left(F_{1,309}=0.10, P=0.75\right)$. Similarly, factor levels describing type 1 and 4 mosquitoes were lumped together $\left(F_{1,310}=0.0078, P=0.93\right)$. The resulting model explained $81.1 \%$ of the total deviance and the residuals were normally distributed (Shapiro-Wilk test, $W=0.9879, P=$ 0.75). Each locus had a significant effect on wing length (ace1: $F_{1,311}=9.93, P=0.0018$; Ester: $F_{2,311}=4.38, P=$ 0.0133). The effect of Ester was due to a significant effect of both type $14\left(F_{1,311}=6.11, P=0.0140\right)$ and type 1 or 4 $\left(F_{1,311}=5.02, P=0.0258\right)$ resistance phenotypes. For both locus, the mean effect of resistance phenotypes was a decrease in wing length compared to susceptible individuals. The reduction in wing length was similar in both sites and both replicates, due to the independent effect of $A C E 1$ and ESTER relatively to the other variables. Due to the nonsignificant interaction ESTER.ACE1 $\left(F_{6,303}=1.48, P=0.185\right)$, these single locus effects were additive. The different resistance phenotypes had a decrease of around $0.0-0.21 \mathrm{~mm}$ (or $0.0-6.4 \%$ ) in wing length, when compared to susceptible mosquitoes (see Table 3 ).

\section{Fluctuating Asymmetry}

For the three sections, FA was significantly $(P<0.0001)$ higher than the measurement error. There was no evidence of DA for sections 2 and 3, but section 1 of the left wing 
TABLE 3. Effect of resistance genes on wing length. Estimates for the double susceptible class (mosquitoes 0 and SS) were used as a reference to calculate the additional effects of resistance genes, according to the resistance phenotype at ace-1 and Ester. The reduction in wing length was similar in both breeding sites and both replicates. Some phenotypes were pooled because their estimated values were not different from one another. See text for explanations.

\begin{tabular}{|c|c|c|c|c|c|c|c|c|}
\hline \multirow[b]{3}{*}{ Density 1} & \multirow{3}{*}{$\begin{array}{l}\text { Wing length estimate } \\
(\mathrm{mm}) \text { for } \mathrm{SS} \text { and } 0\end{array}$} & \multicolumn{7}{|c|}{ Resistance phenotype } \\
\hline & & \multirow[b]{2}{*}{ Ester: } & \multicolumn{3}{|c|}{ ace-1: SS or RS } & \multicolumn{3}{|c|}{ RR } \\
\hline & & & 0 & 1 or 4 & 14 & 0 & 1 or 4 & 14 \\
\hline 300 & 3.83 & & 0 & -0.04 & -0.12 & -0.08 & -0.12 & -0.21 \\
\hline 1000 & 3.27 & & 0 & -0.04 & -0.12 & -0.08 & -0.12 & -0.21 \\
\hline
\end{tabular}

${ }^{1}$ Initial number of larvae per tube.

was significantly (paired $t$-test, $P<0.01$ ) longer than that of the right wing on average.

For sections 1 and 2, FA1 was not dependent on trait size (for section 1: $R^{2}=0.00006, P=0.90$; for section $2: R^{2}=$ $0.015, P=0.0471$ and when two outliers were removed, $R^{2}$ $=0.0010, P=0.108)$. Therefore, for these two sections, FA1 was used as the FA index. Conversely, for section 3, FA1 was positively correlated with $(\mathrm{R}+\mathrm{L}) / 2\left(R^{2}=0.026, P=\right.$ $0.0112)$. Therefore, for this third section, $[|\mathrm{R}-\mathrm{L}| /((\mathrm{R}+\mathrm{L}) /$ $2)$ ] averaged over the two replicates (referred to as FA2) was used as the FA index. For the FA indices on sections 1 and 3 , model simplification indicates that the minimal adequate model was the null model; that is, none of the variables considered or their interactions had a significant effect on FA (Table 4). For FA1 on section 2, the model was reduced to the DENSITY variable, with a significant $\left(F_{1,242}=9.702\right.$, $P=0.0021)$ decrease in FA between the lowest and the two highest densities, corresponding to a variation of $28 \%$. There were no differences in FA between the two highest densities (300 and 1000 larvae/tube, $F_{1,241}=0.101, P=0.75$ ).

\section{DISCUSSION}

\section{Pleiotropic Effects Associated with Insecticide Resistance Alleles}

Our results show that resistance alleles at ace-1 and Ester are associated with pleiotropic effects during the preimaginal stage in natural breeding sites. Almost all combinations of resistance alleles at ace-1 and Ester induced a shorter wing length (up to about $6 \%$ ) and this effect was additive across both loci. The only exception was ace- $1^{R S}$ since RS and SS had similar wing length. Knowing the positive relationship between wing length and fitness (see Materials and Methods section), a tentative conclusion is that ace-1 ${ }^{R}$, Ester ${ }^{1}$, and Ester $^{4}$ reduce fecundity by reducing body size. However, this conclusion must be considered with caution: in conditions where food is limited and in the presence of parasites, larger mosquitoes may be less fecund than smaller ones (Koella and Offenberg 1999). Indeed, when larvae of Aedes aegypti infested by the microsporidian Edhazardia aedis were reared at low food availability, Koella and Offenberg (1999) found a negative relationship between adult size and fecundity.

Our study shows that in natural populations all ace- 1 and Ester resistance alleles induced a longer larval developmental time (up to about $15 \%$ ). However, this cost is variable: the effects of Ester ${ }^{1}$ and Ester ${ }^{4}$ varied with larval density and were not additive with those of ace- $1^{R}$ and ace- $1^{R S}$. Conversely, the effect of these two ace-1 resistance alleles was constant across density levels. Previous field studies also suggested that environmental conditions influence the pleiotropic effects of Ester resistance alleles, although this is not apparent for ace-1 (Chevillon et al. 1997; Gazave et al. 2001).

\section{Asymmetry, Resistance Genes, and Developmental Stress}

Insecticide resistance alleles and FA.-One may predict that insecticide-resistant individuals will exhibit greater fluctuating asymmetry than will susceptible ones (McKenzie 1990; Batterham et al. 1996). This may be important since Møller's reviews $(1997,1999)$ showed that symmetrical individuals have a higher fitness than more asymmetrical ones (but see Markow 1995; Leung and Forbes 1996; Markow et al. 1996; Clarke 1998; Bourguet 2000).

The present study failed to reveal a relationship between wing FA and the presence of insecticide resistance alleles in the mosquito Culex pipiens. To date, the best example of such a relationship is provided by the blowfly Lucilia cuprina (Clarke 1997). In this species, the diazinon resistance allele at the Rop-1 locus and the dieldrin resistance allele at the $R d l$ locus are both associated with increased fluctuating asymmetry (McKenzie and Clarke 1988; McKenzie and Yen 1995; Clarke et al. 2000). Both alleles are also associated with fitness costs in insecticide-free environments (e.g., McKenzie 1990, McKenzie 1994).

TABLE 4. Effect of the resistance genes on unsigned asymmetry $(|\mathrm{R}-\mathrm{L}|$ for sections 1 and 2 and $[|\mathrm{R}-\mathrm{L}| /((\mathrm{R}+\mathrm{L}) / 2)]$ for section $3)$ averaged over the two replicate measurements for the three sections measured.

\begin{tabular}{|c|c|c|c|c|c|c|c|c|c|}
\hline \multirow[b]{2}{*}{ Resistance gene } & \multicolumn{3}{|c|}{ Section 1} & \multicolumn{3}{|c|}{ Section 2} & \multicolumn{3}{|c|}{ Section 3} \\
\hline & $F$ & $\mathrm{df}$ & $P$-value & $F$ & $\mathrm{df}$ & $P$-value & $F$ & $\mathrm{df}$ & $P$-value \\
\hline ace-1 & 0.284 & $(2,230)$ & 0.75 & 0.232 & $(2,226)$ & 0.79 & 0.851 & $(2,217)$ & 0.43 \\
\hline Ester & 1.248 & $(3,230)$ & 0.29 & 0.300 & $(3,226)$ & 0.83 & 0.377 & $(2,217)$ & 0.69 \\
\hline
\end{tabular}


We propose four hypotheses to explain why the costly resistance alleles of Culex pipiens do not affect wing symmetry. One is that FA on wing length of Culex pipiens has no heritable genetic component as suggested by the recent work of Mpho et al. (2002). The second is that allelic variations at ace-1 and Ester do not impair the developmental stability of any morphological characteristics. The third is that the resistance alleles disrupt a restricted number of traits, which do not include the wing (e.g., Clarke et al. 2000). Finally, we cannot exclude the possibility that some modifier alleles compensating the increase in wing FA were present in the natural populations of C. pipiens studied (e.g. Clarke and McKenzie 1987; McKenzie and Clarke 1988; Davies et al. 1996).

Environmental stress and FA.-Environmental stress is known to increase levels of FA (recent examples in Woods et al. 1999; Chapman and Goulson 2000; Clarke et al. 2000; Hosken et al. 2000 but see David et al. 1998; Floate and Fox 2000). In C. pipiens, Mpho et al. (2002) reported evidence for an increase in wing FA with increase in temperature stress. However, and as hypothesized by Parsons (1992) and Leung et al. (2000), this effect was only detected in extreme temperature conditions (Mpho et al. 2002). The present experiment also shows that the detection of changes in FA required relatively severe environmental stress. However, the trend was not as expected. For one of the three wing sections we found a larger FA at 150 larvae per tube than at the two highest density levels (i.e. 300 and 1000 larvae per tube). One explanation may be differential survival between symmetric and asymmetric individuals; mosquitoes surviving at the highest density levels may represent a nonrandom subset of the starting population, which includes the more symmetrical mosquitoes. This hypothesis has been referred to as the "differential mortality hypothesis" by Floate and Fox (2000).

\section{Variability of Fitness Costs and Adaptive Changes}

In $C$. pipiens, the overall fitness costs associated with ace1 (referred to as $c_{a}$ ) and Ester (referred to as $c_{e}$ ) have been estimated by analyzing seasonal variations in geographic gradients of resistance allele frequency in natural populations (Lenormand et al. 1998b, 1999; Lenormand and Raymond 2000). Selection was not detected during the migration between the breeding site and the overwintering caves (Lenormand and Raymond 2000). During the winter (November to March), the lower survival of resistant overwintering females indicates a strong fitness cost for both resistance genes: $c_{a}=0.51$ and $c_{e}=0.26$ (Lenormand et al. 1999; Lenormand and Raymond 2000). These fitness costs were consistent with previous estimates during the same season (Chevillon et al. 1997; Gazave et al. 2001). Finally, during the breeding season, the fitness cost was still substantial at the two resistance loci with $c_{a}=0.11$ and $c_{e}=0.06$ (Lenormand et al. 1998b, 1999). Our results strengthen this conclusion and show that several components of fitness are modified during both larval and adult stages: a lower probability of surviving in crowded conditions, a longer preimaginal stage and a putative lower fecundity of the females. Moreover, the present data are in agreement with the conclusion that $c_{a}$ is higher than $c_{e}$.
As proposed by Lenormand et al. (1998b), the longer larval development time may be expressed in terms of fitness cost. Considering an exponential growth phase with a fecundity between five and 25 offspring per female, an increase of the generation time of about $8 \%$ for ace- $l^{R}$ gives estimates of fitness cost between 0.11 and 0.22 . For type 1 individuals, the increase of larval development time corresponds to a fitness cost between 0.01 and 0.34 depending on the density and fecundity considered. Finally, type 4 individuals suffer variable pleiotropic effects ranging from a positive selective effect of 0.07 to a fitness cost of 0.19. Unfortunately, these estimates cannot be compared with those globally estimated by clinal analysis by Lenormand et al. (1998b, 1999). Indeed, the nonadditive effect of the resistance alleles, their pleiotropic effects on other components of the fitness, and the influence of environmental conditions preclude any calculation of an overall estimate of fitness costs during the breeding season.

Fitness costs are likely to be lowered by subsequent evolution. One possibility is the selection of modifier alleles at other genes that minimize the deleterious effects of resistance alleles in the absence of insecticides (Roush and McKenzie 1987). A modifier allele has been reported in the blowfly Lucilia cuprina for the costly diazinon resistant allele at the Rop-1 locus (Clarke and McKenzie 1987; McKenzie and Clarke 1988; Davies et al. 1996). This modifier dominantly reduces the fitness cost so that, in the absence of diazinon, susceptible and resistant blowflies have equal fitness and a similar level of fluctuating asymmetry (Clarke and McKenzie 1987). A second possibility is the replacement of a costly resistance allele by a less costly one at the same locus. This scenario has received little support (but see Cohan et al. 1994). Now, long-term studies on Culex pipiens have shown that Ester ${ }^{1}$ and ace- $I^{R}$ are progressively replaced by Ester ${ }^{4}$ and ace- $1^{R S}$, respectively (Guillemaud et al. 1998; Lenormand et al. 1998a). Considering that the overproduced esterases A1 and A4-B4 confer approximately the same level of insecticide resistance, Guillemaud et al. (1998) suggested that the replacement of Ester ${ }^{1}$ by Ester ${ }^{4}$ at the Ester locus resulted from a difference in the fitness cost associated with these two alleles. The same explanation has been proposed for the replacement of ace- $1^{R}$ by ace- $1^{R S}$ at the ace- 1 locus: because the level of insecticide resistance conferred by the ace- $1^{R S}$ allele is intermediate between those conferred by the ace- $1^{R}$ and $a c e-1^{S}$ alleles, Lenormand et al. (1998a) hypothesized that $a c e-1^{R S}$ is less costly than ace- $1^{R}$. The present results give support to this idea for the Ester locus, because the lower fitness costs associated with the new adaptive allele $\left(\right.$ Ester $\left.^{4}\right)$ may have been one of the driving forces causing the decrease in the frequency of the first selected allele (Ester $\left.{ }^{1}\right)$.

\section{ACKNOWLEDGMENTS}

We are grateful to C. Bernard, M. Marquine, and G. Pistre for technical assistance, and V. Durand for bibliographic help. We thank two anonymous reviewers for helpful comments. This work was financed in part by the Ministère de l'Aménagement du Territoire et de l'Environnement (PE00/ 122000/024) and by the Institut National de la Recherche Agronomique. DB benefited from a fellowship from the Min- 
istère de l'Enseignement Supérieur et de la Recherche (no. 93082). This is contribution ISEM 03-091 of the Institut des Sciences de l'Evolution, Université Montpellier, France.

\section{Literature Cited}

Agnew, P., and J. C. Koella. 1999. Life history interactions with environmental conditions in a host-parasite relationship and the parasite's mode of transmission. Evol. Ecol. 13:67-89.

Alyokhin, A. V., and D. N. Ferro. 1999. Relative fitness of Colorado potato beetle (Coleoptera: Chrysomelidae) resistant and susceptible to the Bacillus thuringiensis Cry3A toxin. J. Econ. Entomol. 92:510-515.

Amin, A. M., and G. B. White. 1984. Relative fitness of organophosphate-resistant and susceptible strains of Culex quinquefasciatus Say (Diptera: Culicidae). Bull. Entomol. Res. 74:591-598.

Anderson, D. I., and B. R. Levin. 1999. The biological cost of antibiotic resistance. Curr. Opin. Microbiol. 2:489-493.

Argentine, J. A., J. M. Clark, and D. N. Ferro. 1989. Relative fitness of insecticide-resistant Colorado potato beetle strains (Coleoptera: Chrysomelidae). Environ. Entomol. 18:705-710.

Baker, J. E., J. Perez-Mendoza, R. W. Beeman, and J. E. Throne. 1998. Fitness of a malathion-resistant strain of the parasitoid Anisopteromalus calandrae (Hymenoptera: Pteromalidae). J. Econ. Entomol. 91:50-55.

Baker, R. J. 1987. GLIM 3.77 reference manual. Numerical Algorithms Group, Oxford, U.K.

Batterham, P., A. G. Davies, A. Y. Game, and J. A. McKenzie. 1996. Asymmetry-where evolutionary and developmental genetics meet. Bioessays 18:841-845.

Bergelson, J., and C. B. Purrington. 1996. Surveying patterns in the cost of resistance in plants. Am. Nat. 148:536-558.

Bourguet, D. 2000. Fluctuating asymmetry and fitness in Drosophila melanogaster. J. Evol. Biol. 13:515-521.

Bourguet, D., M. Raymond, D. Fournier, C. A. Malcolm, J.-P. Toutant, and M. Arpagaus. 1996a. Existence of two acetylcholinesterases in the mosquito Culex pipiens (Diptera: Culicidae). J. Neurochem. 67:2115-2123.

Bourguet, D., M. Raymond, J. Bisset, N. Pasteur, and M. Arpagaus. 1996b. Duplication of the Ace.1 locus in Culex pipiens mosquitoes from the Caribbean. Biochem. Genet. 34:351-362.

Briegel, H. 1990. Fecundity, metabolism, and body size in Anopheles (Diptera: Culicidae), vectors of malaria. J. Med. Entomol 27:839-850.

Campanhola, C., B. F. McCutchen, E. H. Baehrecke, and F. W. Plapp. 1991. Biological constraints associated with resistance to pyrethroids in the tobacco budworm (Lepidoptera: Noctuidae). J. Econ. Entomol. 84:1404-1411.

Chapman, J. W., and D. Goulson. 2000. Environmental versus genetic influences on fluctuating asymmetry in the house fly, Musca domestica. Biol. J. Linn. Soc. 70:403-413.

Charlesworth, B. 1980. Evolution in age-structured populations. Cambridge Univ. Press, Cambridge, U.K.

Chevillon, C., N. Pasteur, M. Marquine, D. Heyse, and M. Raymond. 1995. Population structure and dynamics of selected genes in the mosquito Culex pipiens. Evolution 49:997-1007.

Chevillon, C., D. Bourguet, F. Rousset, N. Pasteur, and M. Raymond. 1997. Pleiotropy of adaptive changes in populations: comparisons among insecticide resistance genes in Culex pipiens. Genet. Res. 70:195-204.

Clarke, G. M. 1997. The genetic and molecular basis of developmental stability-the Lucilia story. Trends. Ecol. Evol. 12: 89-91.

_ 1998. Developmental stability and fitness: the evidence is not quite so clear. Am. Nat. 152:762-766.

Clarke, G. M., and J. A. McKenzie. 1987. Developmental stability of insecticide resistance phenotypes in blowfly: a result of canalizing natural selection. Nature 325:345-346.

Clarke, G. M., J. L. Yen, and J. A. McKenzie. 2000. Wings and bristles: character specificity of the asymmetry phenotype in insecticide-resistant strains of Lucilia cuprina. Proc. R. Soc. Lond. B 267:1815-1818.
Clements, A. N. 1992. The biology of mosquitoes. Vol. 1. Development, nutrition and reproduction. Chapman and Hall, London.

Cochran, D. G. 1993. Decline of prethroid resistance in the absence of selection pressure in a population of German cockroaches (Dictyoptera: Blatellidae). J. Econ. Entomol. 86:1639-1644.

Cohan, F. M., E. C. King, and P. Zawadzki. 1994. Amelioration of the deleterious effects of an adaptive mutations in Bacillus subtilis. Evolution 48:81-95.

Coustau, C., C. Chevillon, and R. ffrench-Constant. 2000. Resistance to xenobiotics and parasites: Can we count the cost? Trends Ecol. Evol. 15:378-383.

Crawley, M. J. 1993. GLIM for ecologists. Blackwell Scientific Publications, Oxford, U.K.

Crow, J. F. 1957. Genetics of insecticide resistance to chemicals. Annu. Rev. Entomol. 2:227-246.

Daly, J. C., and G. P. Fitt. 1990. Resistance frequencies in overwintering pupae and the first spring generation of Helicoverpa armigera (Hübner) (Lepidoptera: Noctuidae): selective mortality and immigration. J. Econ. Entomol. 83:1682-1688.

David, P., A. Hingle, D. Greig, A. Rutherford, A. Pomiankowski, and K. Fowler. 1998. Male sexual ornament size but not asymmetry reflects condition in stalk-eyed flies. Proc. R. Soc. Lond. B 265:2211-2216.

Davies, A. G., A. Y. Game, Z. Z. Chen, T. J. Williams, S. Goodall, J. L. Yen, J. A. McKenzie, and P. Batterham. 1996. Scalloped wings is the Lucilia cuprina Notch homologue and a candidate for the Modifier of fitness and asymmetry of diazinon resistance. Genetics 143:1321-1337.

DeStordeur, E. 1976. Esterases in the mosquito Culex pipiens pipiens L.: formal genetics and polymorphism of adult esterases. Biochem. Genet. 14:481-493.

Floate, K. D., and A. S. Fox. 2000. Flies under stress: a test of fluctuating asymmetry as a biomonitor of environmental quality. Ecol. Appl. 10:1541-1550.

Foster, S. P., C. M. Woodcock, M. S. Williamson, A. L. Devonshire, I. Denholm, and R. Thompson. 1999. Reduced alarm response by peach-potato aphids Myzus persicae (Hemiptera: Aphididae) with knock-down resistance to insecticides $(k d r)$ may impose a fitness cost through increased vulnerability to natural enemies. Bull. Entomol. Res. 89:133-138.

Gazave, E., C. Chevillon, T. Lenormand, M. Marquine, and M. Raymond. 2001. Dissecting the cost of insecticide resistance genes during the overwintering period of mosquito Culex pipiens. Heredity 87:441-448.

Guillemaud, T., T. Lenormand, D. Bourguet, C. Chevillon, M. Raymond, and N. Pasteur. 1998. Evolution of resistance in Culex pipiens: allele replacement and changing environment. Evolution 52:443-453.

Heather, N. W. 1982. Comparison of population growth rates of malathion resistant and susceptible populations of the rice weevil, Sitopilus oryzae (Linnaeus) (Coleoptera: Curculionidae). Queensl. J. Agric. Anim. Sci. 39:61-68.

Hollingworth, R. G., B. E. Tabashnik, M. W. Johnson, R. H. Messing, and D. E. Ullman. 1997. Relationship between susceptibility to insecticides and fecundity across populations of cotton aphid (Homoptera: Aphididae). J. Econ. Entomol. 90:55-58.

Hosken, D. J., W. U. Blanckenhorn, and P. I. Ward. 2000. Developmental stability in yellow dong flies (Scathophaga stercoraria): fluctuating asymmetry, heterozygosity and environmental stress. J. Evol. Biol. 13:919-926.

Koella, J. C., and J. Offenberg. 1999. Food availability and parasite infection influence the correlated responses of life history traits to selection for age at pupation in the mosquito Aedes aegyti. J. Evol. Biol. 12:760-769.

Lenormand, T., and M. Raymond. 2000. Analysis of cline with variable selection and variable migration. Am. Nat. 155:70-82.

Lenormand, T., T. Guillemaud, D. Bourguet, and M. Raymond. 1998a. Appearance and sweep of a gene duplication: adaptive response and potential for new functions in the mosquito Culex pipiens. Evolution 52:1705-1712.

1998b. Evaluating gene flow using selected markers: a case study. Genetics 149:383-1392.

Lenormand, T., D. Bourguet, G. Guillemaud, and M. Raymond. 
1999. Tracking the evolution of insecticide resistance in the mosquito Culex pipiens. Nature 400:861-864.

Leung, B., and M. R. Forbes. 1996. Fluctuating asymmetry in relation to stress and fitness: effects of trait type as revealed by meta-analysis. Ecoscience 3:400-413.

Leung, B., M. R. Forbes, and D. Houle. 2000. Fluctuating asymmetry as a bioindicator of stress: comparing efficacy of analyses involving multiple traits. Am. Nat. 155:101-115.

Malcolm, C. A., D. Bourguet, A. Ascolillo, S. J. Rooker, C. F. Garvey, L. C. M. Hall, N. Pasteur, and M. Raymond. 1998. A sex-linked Ace gene, not linked to insensitive acetylcholinesterase mediated insecticide resistance in Culex pipiens. Insect Mol. Biol. 7:107-120.

Markow, T. A. 1995. Evolutionary ecology and developmental instability. Annu. Rev. Entomol. 40:105-120.

Markow, T. A., D. Bustoz, and S. Pitnick. 1996. Sexual selection and a secondary sexual character in two Drosophila species. Anim. Behav. 52:759-766.

McKenzie, J. A. 1990. Selection at the dieldrin resistance locus in overwintering populations of Lucilia cuprina (Wiedemann). Aust. J. Zool. 38:493-501.

—_ - 1994. Selection at the diazinon resistance locus in overwintering populations of Lucilia cuprina (the Australian sheep blowfly). Heredity 73:57-64.

McKenzie, J. A., and G. M. Clarke. 1988. Diazinon resistance, fluctuating asymmetry and fitness in the Australian sheep blowfly, Lucilia cuprina. Genetics 120:213-220.

McKenzie, J. A., and J. L. Yen. 1995. Genotype, environment and the asymmetry phenotype. Dieldrin-resistance in Lucilia cuprina (the Australian sheep blowfly). Heredity 75:181-187.

McKenzie, J. A., M. J. Whitten, and M. A. Adena. 1982. The effect of genetic background on the fitness of diazinon resistance genotypes of the Australian sheep blowfly, Lucilia cuprina. Heredity 49:1-9.

Møller, A. P. 1997. Developmental stability and fitness. Am. Nat. 149:916-932.

1999. Asymmetry as a predictor of growth, fecundity, and survival. Ecol. Lett. 2:149-156.

Moeur, J. E., and C. A. Istock. 1980. Ecology and evolution of the pitcher-plant mosquito. IV. Larval influence over adult reproductive performance and longevity. J. Anim. Ecol. 49:775-792.

Mpho, M., A. Callaghan, and G. J. Holloway. 2002. Temperature and genotypic effects on life history and fluctuating asymmetry in a field strain of Culex pipiens. Heredity 88:307-312.

Nasci, R. S. 1986. Relationship between adult mosquito (Diptera: Culicidae) body size and parity in field populations. Environ. Entomol. 15:874-876.

Packer, M. J., and P. S. Corbet. 1989. Size variation and reproductive success of female Aedes punctor (Diptera: Culicidae). Ecol. Entomol. 14:297-309.

Palmer, A. R. 1994. Fluctuating asymmetry analyses: a primer. Pp. 335-364 in T. A. Markow, ed. Developmental instability: its origins and evolutionary implications. Kluwer Academic Publishers, Dordrecht, The Netherlands.

Palmer, A. R., and C. Strobeck. 1986. Fluctuating asymmetry: measurement, analysis, patterns. Annu. Rev. Ecol. Syst. 17:391-421.

Parsons, P. A. 1992. Fluctuating asymmetry-a biological monitor of environmental and genomic stress. Heredity 68:361-364.

Pasteur, N., A. Iseki, and G. P. Georghiou. 1981a. Genetics and biochemical studies of highly active esterases A and B associated with organophosphate resistance in mosquitoes of the Culex pipiens complex. Biochem. Genet. 19:909-919.

Pasteur, N., G. Sinègre, and A. Gabinaud. 1981b. Est-2 and Est-3 polymorphism in Culex pipiens L. from southern France in re- lation to organophosphate resistance. Biochem. Genet. 19: 499-508.

Pasteur, N., G. Pasteur, F. Bonhomme, and J. Britton-Davidian. 1988. Practical isozyme genetics. Ellis Horwood Ltd, Chichester, England.

Raymond, M., and M. Marquine. 1994. Evolution of insecticide resistance in Culex pipiens populations: the Corsican paradox. J. Evol. Biol. 7:315-337.

Raymond, M., E. Poulin, V. Boiroux, E. Dupont, and N. Pasteur. 1993. Stability of insecticide resistance due to amplification of esterase genes in Culex pipiens. Heredity 70:301-307.

Raymond, M., C. Berticat, M. Weill, N. Pasteur, and C. Chevillon. 2001. Insecticide resistance in the mosquito Culex pipiens: What have we learned about adaptation? Genetica 112/113:287-296.

Roff, D. A. 1992. The evolution of life histories: theory and analysis. Chapman \& Hall, New York.

Rooker, S. J., T. Guillemaud, J.-B. Bergé, N. Pasteur, and M. Raymond. 1996. Coamplification of esterase A and B genes as a single unit in Culex pipiens mosquitoes. Heredity 77:555-561.

Roush, R. T., and J. C. Daly. 1990. The role of population genetics in resistance research and management. Pp. 97-152 in R. T. Roush and B. E. Tabashnik, eds. Pesticide resistance in arthropods. Chapman and Hall, New York.

Roush, R. T., and J. A. McKenzie. 1987. Ecological genetics of insecticide and acaricide resistance. Annu. Rev. Entomol. 32: $361-380$

Simms, E. L., and M. D. Rausher. 1987. Costs and benefits of plant resistance to herbivory. Am. Nat. 130:570-581.

Simms, E. L., and J. Triplett. 1994. Costs and benefits of plant response to disease: resistance and tolerance. Evolution 48: 1973-1985.

Stearns, S. C. 1992. The evolution of life histories. Oxford Univ. Press, Oxford, U.K.

Taylor, M., and R. Feyereisen. 1996. Molecular biology and evolution of resistance to toxicants. Mol. Biol. Evol. 13:719-734.

Varzandeh, M., W. N. Bruce, and G. C. Decker. 1954. Resistance to insecticides as a factor influencing the biotic potential of the house fly. J. Econ. Entomol. 47:129-134.

Weill, M., P. Fort, A. Berthomieu, M.-P. Dubois, N. Pasteur, and M. Raymond. 2002. A novel acetylcholinesterase gene in mosquitoes codes for the insecticide target and is non-homologous to the ace gene in Drosophila. Proc. R. Soc. Lond. B 269: 2007-2016.

Whitehead, J. R., R. T. Roush, and B. R. Norment. 1985. Resistance stability and coadaptation in diazinon-resistant house flies (Diptera: Muscidae). J. Econ. Entomol. 78:25-29.

Woods, R. E., C. M. Sgro, M. J. Hercus, and A. A. Hoffmann. 1999. The association between fluctuating asymmetry, trait variability, trait heritability, and stress: a multiply replicated experiment on combined stresses in Drosophila melanogaster. Evolution 53: 493-505.

Yan, G., D. W. Severson, and B. M. Christensen. 1997. Costs and benefits of mosquito refractoriness to malaria parasites: implications for genetic variability of mosquitoes and genetic control of malaria. Evolution 51:441-450.

Zhai, J., and W. H. Robinson. 1996. Instability of cypermethrin resistance in a field population of the German cockroach (Orthoptera: Blatellidae). J. Econ. Entomol. 89:332-336.

Zhu, K. Y., S. H. Lee, and J. M. Clark. 1996. A point mutation of acetylcholinesterase associated with azinphosmethyl resistance and reduced fitness in Colorado potato beetle. Pest. Biochem. Physiol. 55:100-108. 